\title{
Radiography Study File
}

National Cancer Institute

\section{Source}

National Cancer Institute. Radiography Study File. NCI Thesaurus. Code C115721.

Records pertaining to radiographic files. 